4 Kozin F, Ginsberg M H, Skosey J L. Polymorphonuclear leukocyte responses to monosodium urate crystals: modification by adsorbed serum proteins. $J$ Rheumatol 1979; 6: 519-26.

5 Russell I J, Mansen C, Kolb L M, Kolb W P. Activation of the fifth component of human complement (C5) induced by monosodium urate crystals: $\mathrm{C} 5$ convertase assembly on the crystal surface. Clin Immunol Immunopathol 1982; 24: 239-50.

6 Nelson R D, Quie P G, Simmons R L. Chemotaxis under agarose: a new and simple method for measuring chemotaxis and spontaneous migration of human polymorphonuclear leukocytes and monocytes. J Immunol 1975; 115: $1650-6$.

\title{
Inflammatory effect of aluminium phosphate
}

\author{
P. NETTER, J. L. DELONGEAS, G. FAURE, P. BOZ, D. B URNEL, J. L. FOL I GUET, \\ M. F. KESSLER, R. J. ROYER, A. GA UCHER
}

From the Travail de la Clinique Rhumatologique, des Laboratoires de Pharmacologie, d Anatomie pathologique, de Chimie et d'Histologie, et du Service de Néphrologie, Faculté de Médecine de Nancy, Université de Nancy I, 54500 Vandoeuvre les Nancy, France

Microcrystalline-induced arthritis is known to occur in patients undergoing haemodialysis for chronic renal insufficiency. The following microcrystals have been implicated so far in these inflammatory phenomena: apatite, calcium pyrophosphate dihydrate (CPPD), and sodium monourate.

In preliminary study, ${ }^{12}$ using scanning electron microscopy (SEM) and wavelength dispersive microanalysis (WDM), we found aluminium deposits associated with phosphate in synovial tissue from a patient undergoing haemodialysis because of chronic renal insufficiency, who had been taking aluminium hydroxide for five years. Aluminium concentrations measured with a sensitive and reproducible pulse polarography method were raised in the synovial fluid $(87 \mu \mathrm{g} / \mathrm{l})$, synovial tissue $(3.7$ and $2.2 \mu \mathrm{g} / \mathrm{g}$ wet weight) and in the cartilage $(22 \mu \mathrm{g} / \mathrm{g}$ wet weight) compared with controls: synovial fluid: $10 \cdot 8 \pm 5 \mu \mathrm{g} / \mathrm{l}(\mathrm{n}=6)$, synovial tissue: $0 \cdot 8 \pm 0 \cdot 2 \mu \mathrm{g} / \mathrm{g}(\mathrm{n}=4)$, cartilage: $8 \cdot 31 \pm 2 \cdot 0 \mu \mathrm{g} / \mathrm{g}(\mathrm{n}=4)$. Transmission electron microscopy (TEM) revealed electron dense material of microfibrillar appearance in lysosomes of macrophagic synovial cells.

In a second part we developed experimental models to appreciate the prophlogistic properties of aluminium phosphate using two different animal models: (a) paw oedema after subcutaneous injection in the rear foot pad of Sprague Dawley rats and $(b)$ experimental arthritis after intra-articular injection in rabbits.

Tribasic aluminium phosphate was compared to calcium hydrogen phosphate dihydrate previously found during destructive chondrocalcinosis in humans ${ }^{4}$; natural diamond powder and lambda carrageenan were chosen as negative and positive controls.

In the first model, inflammation induced by aluminium phosphate reached its maximum as soon as 15-30) min after injection but lasted only 24 hours. The response to calcium hydrogen phosphate dihydrate was only minor whereas carregeenaninduced inflammation appeared after two hours but was far greater and lasted mored than 24 hours.

The second experimental proceeding was used to evaluate the histological consequences of the injection of these compounds on synovial tissue and cartilage. Rabbits were injected in the knee joints every day for three days. Aluminium phosphate can induce, like carrageenan, inflammatory lesions of the synovial tissue and erosive damage of the articular cartilage. With TEM, lysosomal inclusions of phagocytosed material with microfilaments were seen. Through SEM coupled with a wavelength dispersive microprobe analysis, aluminium associated with phosphate was found in cellular elements. These features are similar to those observed in the patient in our preliminary study and those described in cerebral tissue from patients with aluminium intoxication.

The inflammatory effect demonstrated in this study suggests that in addition to apatite, calcium pyrophosphate dihydrate and sodium monourate, aluminium compounds could play a part in clinical manifestations observed in patients with chronic renal insufficiency undergoing haemodialysis and receiving aluminium gels.

\section{References}

1 Netter P, Burnel D, Hutin M F, Kessler $M F$. Faure G. Aluminium in joint tissues of patient taking aluminium hydroxide. Lancet 1981; i: 1056-7.

2 Netter P. L'aluminium dans l'os, le cartilage, la membrane synoviale et le liquide synovial. University of Nancy, Nancy, 1980. Thesis.

3 Royer R J, Delongeas J L, Netter P, et al. Inflammatory effect of aluminium on rat paws. Pathol Biol (Paris) 1982; 30: 211-5.

4 Faure G, Netter P, Malaman B. Steinmetz J. Monocrystalline calcium hydrogen phosphate dihydrate in destructive arthropathies of chondrocalcinosis. Lancet 1977; ii: 142-3. 